\title{
Perlindungan Status Kerja Dan Pengupahan Tenaga Kerja Dalam Situasi Pandemi COVID-19 Berdasarkan Perspektif Pembaharuan Hukum
}

\author{
Kanyaka Prajnaparamitha, Mahendra Ridwanul Ghoni \\ Fakultas Hukum, Universitas Diponegoro \\ Jl. Prof. Soedarto, S.H., Tembalang, Semarang. \\ Email: anya_fh@yahoo.com, mhdrigo@gmail.com
}

\begin{abstract}
The study aims to determine the protection of work status and remuneration for workers in a co-19 pandemic situation based on the perspective of legal reform. The results showed that in terms of wage protection and protection for workers in the workplace the employer can hold the payment of wages (if the employer is unable to pay wages according to the minimum wage), by first negotiating with workers / laborers or related trade unions / labor unions the suspension. The suspension of payment of the minimum wage by the employer to the worker / laborer does not necessarily eliminate the obligation of the employer to pay the difference in the minimum wage during the suspension period. Then, according to the DKI Jakarta Provincial Manpower, Transmigration and Energy Office Circular Letter Number 14 / SE / 2020 Year 2020 concerning Work From Home Appeals, company leaders are expected to take preventative steps related to the risk of transmitting COVID-19 infections with do homework.
\end{abstract}

Keywords: Work Status, Wages, Labor, Pandemic, COVID-19

\begin{abstract}
Abstrak
Penelitian bertujuan untuk mengetahui perlindungan status kerja dan pengupahan tenaga kerja dalam situasi pandemi covid-19 berdasarkan perspektif pembaharuan hukum. Hasil penelitian menunjukan bahwa Dalam hal perlindungan pengupahan dan perlindungan bagi tenaga kerja di tempat kerja pengusaha dapat melakukan penangguhan pembayaran upah (jika pengusaha tidak mampu membayar upah sesuai upah minimum), dengan terlebih dahulu melakukan perundingan dengan pekerja/buruh atau serikat pekerja/serikat buruh terkait penangguhan tersebut.Penangguhan pembayaran upah minimum oleh pengusaha kepada pekerja/buruh tidak serta-merta menghilangkan kewajiban pengusaha untuk membayar selisih upah minimum selama masa penangguhan. Kemudian, Menurut Surat Edaran Dinas Tenaga Kerja, Transmigrasi dan Energi Provinsi DKI Jakarta Nomor 14/SE/2020 Tahun 2020 tentang Himbauan Bekerja di Rumah (Work From Home), para pimpinan perusahaan diharapkan dapat mengambil langkah pencegahan terkait risiko penularan infeksi COVID-19 dengan melakukan pekerjaan di rumah.
\end{abstract}

Kata kunci: Status Kerja, Pengupahan, Tenaga Kerja, Pandemi, COVID-19 


\section{A. Pendahuluan}

Penyebaran Corona Virus Disease 2019 (COVID-19) membawa risiko bagi kesehatan masyarakat dan bahkan telah merenggut korban jiwa bagi yang terinfeksi di berbagai belahan penjuru dunia, termasuk Indonesia. Pandemi Corona Virus Disease 2019 (COVID-19) juga secara nyata telah mengganggu aktivitas ekonomi dan membawa implikasi besar bagi perekonomian sebagian besar negara-negara di seluruh dunia, termasuk Indonesia. Pertumbuhan ekonomi global diperkirakan akan menurun dari 3\% (tiga persen) menjadi hanya 1,5\% (satu koma lima persen) atau bahkan lebih rendah dari itu. Perkembangan pandemi Corona Virus Disease 2019 (COVID-19) juga berpotensi mengganggu aktivitas perekonomian di Indonesia. Salah satu implikasinya berupa penurunan pertumbuhan ekonomi Indonesia yang diperkirakan dapat mencapai 4\% (empat persen) atau lebih rendah, tergantung kepada seberapa lama dan seberapa parah penyebaran pandemi Corona Virus Disease 2019 (COVID-19) mempengaruhi atau bahkan melumpuhkan kegiatan masyarakat dan aktivitas ekonomi.

Terganggunya aktivitas ekonomi akan berimplikasi kepada perubahan dalam postur Anggaran Pendapatan dan Belanja Negara (APBN) Tahun Anggaran 2020 baik sisi Pendapatan Negara, sisi Belanja Negara, maupun sisi Pembiayaan. Potensi perubahan APBN Tahun Anggaran 2020 berasal dari terganggunya aktivitas ekonomi atau pun sebaliknya. Gangguan aktivitas ekonomi akan banyak berpotensi mengganggu APBN Tahun Anggaran 2020 dari sisi Pendapatan Negara. Respon kebijakan keuangan negara dan fiskal dibutuhkan untuk menghadapi risiko pandemi Corona Virus Disease 2019 (COVID-19), antara lain berupa peningkatan belanja untuk mitigasi risiko kesehatan, melindungi masyarakat dan menjaga aktivitas usaha. Tekanan pada sector keuangan akan mempengaruhi APBN Tahun Anggaran 2020 terutama sisi Pembiayaan. Implikasi pandemi Corona Virus Disease 2019 (COVID-19) telah berdampak pula terhadap ancaman semakin memburuknya sistem keuangan yang ditunjukkan dengan penurulnan berbagai aktivitas ekonomi domestik karena langkah-langkah penanganan pandemi Corona Virus Disease 2019 (COVID-19) yang berisiko pada ketidakstabilan makroekonomi dan sistem keuangan yang perlu dimitigasi bersama oleh Pemerintah maupun koordinasi kebijakan dalam KSSK, sehingga diperlukan berbagai upaya Pemerintah dan lembaga terkait untuk melakukan tindakan antisipasi (forward looking) untuk menjaga stabilitas sektor keuangan.

Penyebaran pandemi Corona Virus Disease 2019 (COVID-19) yang memberikan dampak dan mengancam pertumbuhan ekonomi Indonesia antara lain 
karena menurunnya penerimaan negara serta ketidakpastian ekonomi global, memerlukan kebijakan dan langkah-langkah luar biasa (extraordinary) di bidang keuangan negara termasuk di bidang perpajakan dan keuangan daerah, dan sektor keuangan, yang harus segera diambil Pemerintah dan lembaga-lembaga terkait guna mengatasi kondisi mendesak tersebut dalam rangka penyelamatan kesehatan, perekonomian nasional, dengan fokus pada belanja kesehatan, jaring pengaman sosial (Social Safety), serta pemulihan dunia usaha yang terdampak. Oleh karena itu, diperlukan perangkat hukum yang memadai untuk memberikan landasan yang kuat bagi Pemerintah dan lembaga-lembaga terkait untuk pengambilan kebijakan dan langkah-langkah dimaksud. Sesuai Putusan Mahkamah Konstitusi Nomor 138/PUUVII/2009, kondisi tersebut di atas telah memenuhi parameter sebagai kegentingan yang memaksa dalam rangka penetapan Peraturan Pemerintah Pengganti Undang-Undang antara lain ${ }^{1}$ :

a) karena adanya kebutuhan mendesak untuk menyelesaikan masalah hukum secara cepat berdasarkan Undang-Undang;

b) Undang-Undang yang dibutuhkan belum ada sehingga terjadi kekosongan hukum atau tidak memadainya Undang-Undang yang saat ini ada; dan

c) kondisi kekosongan hukum yang tidak dapat diatasi dengan cara membuat Undang-Undang secara prosedur biasa yang memerlukan waktu yang cukup lama sedangkan keadaan yang mendesak tersebut perlu kepastian untuk diselesaikan.

Pandemi COVID 19 juga mengakibatkan sebagian besar Pengusaha dipaksa untuk menghentikan atau mengurangi kegiatan usahanya. Ini berarti akan terjadi Pemutusan Hubungan Kerja atau pengurangan para pekerjanya. Hal ini juga memaksa pekerja untuk Work From Home (WFH) atau tidak bekerja sama sekali. Ini berarti berkurangnya atau terhentinya sumber nafkah pekerja / buruh dan keluarganya. Akibat Pandemi COVID 19, bagi Pemerintah Pemutusan Hubungan Kerja adalah bertambahnya jumlah pengangguran yang dapat menimbulkan keresahan sosial ${ }^{2}$.

Untuk menghadapi dan menanggulangi krisis akibat wabah virus corona atau COVID-19, pada tanggal 31 Maret 2020, Presiden Joko Widodo telah menerbitkan Peraturan Pemerintah Pengganti Undang-Undang (PERPU) No. 1 Tahun 2020 dengan

\footnotetext{
${ }^{1}$ Jimly Asshiddiqie, Seminar Nasional Online "PROBLEMATIKA PERPU COVID-19"

2 Aloysius Uwiyono, Seminar Nasional Online "Pemutusan Hubungan Kerja Sepihak Akibat Pandemi COVID 19”, KEPRI LAWYERS CLUB INDONESIA, Jakata, 5 Mei 2020.
} 
judul yang cukup Panjang, yaitu tentang "Kebijakan Keuangan Negara dan Stabilitas Sistem Keuangan untuk Penanganan Pandemi Corona Virus Desease 2019 (Covid-19) dan/atau dalam rangka Menghadapi Ancaman yang Membahayakan Perekonomian Nasional dan/atau Stabilitas Sistem Keuangan"3 . Jika diperhatikan dengan baik, PERPU dapat dipandang sebagai satu contoh penerapan "omnibus law" di Indonesia, bahkan mendahului pembahasan pelbagai rancangan UU yang memang diniatkan oleh Pemerintah sebagai "omnibus law" yang pertama dalam sejarah penerapan ide ini dalam praktik.

Namun, PEPRU Nomor 1 Tahun 2020 belum mengakomodir sepenuhnya terkait dengan dunia ketenagakerjaan. Urusan terkait dengan tenaga kerja sepenuhnya ada di tangan perusahaan dan riskan untuk menimbulkan kesewenang-wenangan perusahaan. Oleh karena itu, dalam jurnal ini akan dikaji dari beberapa rumusan masalah yaitu : Bagaimana perlindungan status kerja dan pengupahan tenaga kerja dalam situasi pandemic COVID-19 saat ini? Dan Bagaimana perlindungan status kerja dan pengupahan tenaga kerja dalam situasi pandemic COVID-19 berdasarkan perspektif pembaharuan hukum?

\section{B. Metode Penelitian}

Penelitian ini menggunakan pendekatan yuridis normatif, yaitu dengan mengkaji atau menganalisis data sekunder yang berupa bahanbahan hukum sekunder dengan memahami hukum sebagai perangkat peraturan atau norma-norma positif di dalam sistem perundang-undangan yang mengatur mengenai kehidupan manusia. Jadi penelitian ini dipahami sebagai penelitian kepustakaan, yaitu penelitian terhadap data sekunder ${ }^{4}$.

Penelitian ini juga akan menggunakan data komparatif undang-undang di Negara lain yang mengatur Perlindungan Status Kerja dan Pengupahan Tenaga Kerja Dalam Situasi Pandemi COVID-19. Data Dianalisis secara kualitatif-normatif dengan jalan menafsirkan dan mengkonstruksikan pernyataan yang terdapat dalam dokumen dan perundang-undangan. Normatif karena penelitian ini bertitik tolak dari peraturan-peraturan yang ada sebagai norma hukum positif, sedangkan kualitatif berarti analisis data yang bertitik tolak pada usaha penemuan asas-asas dan informasi baru.

\footnotetext{
${ }^{3}$ LNRI Tahun 2020 Nomor 87, TLNRI Nomor 6485.

${ }^{4}$ Soerjono Soekanto \& Sri Mamudji, Penelitian Hukum Normatif, Suatu Tinjauan Singkat, Rajawali, Jakarta, Halaman. 15
} 


\section{Pembahasan}

A. Perlindungan Status Kerja Dan Pengupahan Tenaga Kerja Dalam Situasi Pandemic COVID-19 Saat Ini.

\section{a. Perlindungan Status Kerja dan Pengupahan Tenaga Kerja}

1) Pencegahan Pemutusan Hubungan Kerja (PHK)

Pasal 151 ayat (1) Undang-Undang Nomor 13 Tahun 2003 tentang Ketenagakerjaan menegaskan bahwa:

"Pengusaha, pekerja/buruh, serikat pekerja/serikat buruh, dan pemerintah, dengan segala upaya harus mengusahakan agar jangan terjadi pemutusan hubungan kerja."

Jika segala upaya telah dilakukan, tetapi PHK tidak dapat dihindari, maka maksud PHK wajib dirundingkan oleh pengusaha dan serikat pekerja/serikat buruh atau dengan pekerja/buruh apabila pekerja/buruh yang bersangkutan tidak menjadi anggota serikat pekerja/serikat buruh. Pemerintah dalam situasi Pandemi COVID-19 meminta pengusaha tidak melakukan PHK, terutama di sektor-sektor yang rentan terdampak pandemi COVID-19.

Ketua Kebijakan Publik Asosiasi Pengusaha Indonesia, Sutrisno Iwantono, mengakui bahwa imbauan untuk tidak melakukan PHK agak sedikit sulit untuk diterapkan. Terlebih jika perusahaan mengalami kerugian, PHK menjadi hal yang paling mungkin untuk dilakukan oleh pelaku usaha untuk menekan defisit keuangan perusahaan.

Di sisi lain, Menteri Ketenagakerjaan Ida Fauziyah, menyatakan bahwa yang dibutuhkan adalah kerja sama yang mengedepankan dialog sosial untuk mencari solusi terbaik dan menghindari PHK. Dalam rangka menghindari PHK, Kementerian Ketenagakerjaan telah menerbitkan Surat Edaran Menteri Ketenagakerjaan Nomor M/3/HK.04/III/2020 Tahun 2020 tentang Perlindungan Pekerja/Buruh dan Kelangsungan Usaha dalam Rangka Pencegahan dan Penanggulangan COVID-19

Perlindungan pengupahan bagi pekerja/buruh diatur dengan ketentuan sebagai berikut: 
"Melaksanakan Perlindungan Pengupahan bagi Pekerja/Buruh terkait Pandemi COVID-19.

1. Bagi pekerja/buruh yang dikategorikan sebagai Orang Dalam Pemantauan (ODP) COVID-19 berdasarkan keterangan dokter sehingga tidak dapat masuk kerja paling lama 14 hari atau sesuai standar Kementerian Kesehatan, maka upahnya dibayarkan secara penuh.

2. Bagi pekerja/buruh yang dikategorikan kasus suspek COVID19 dan dikarantina/diisolasi menurut keterangan dokter, maka upahnya dibayarkan secara penuh selama menjalani masa karantina/isolasi.

3. Bagi pekerja/buruh yang tidak masuk kerja karena sakit COVID-19 dan dibuktikan dengan keterangan dokter, maka upahnya dibayarkan sesuai peraturan perundang-undangan.

4. Bagi perusahaan yang melakukan pembatasan kegiatan usaha akibat kebijakan pemerintah di daerah masing-masing guna pencegahan dan penanggulangan COVID-19, sehingga menyebabkan sebagian atau seluruh pekerja/buruhnya tidak masuk kerja, dengan mempertimbangkan kelangsungan usaha maka perubahan besaran maupun cara pembayaran upah pekerja/buruh dilakukan sesuai dengan kesepakatan antara pengusaha dengan pekerja/buruh.

Maka, untuk menghindari PHK, pengusaha dapat melakukan perubahan besaran maupun cara pembayaran upah terhadap upah pekerja/buruh yang dirumahkan sementara akibat wabah COVID-19, berdasarkan kesepakatan para pihak. Selain itu, pekerja/buruh yang diduga atau positif terjangkit COVID-19 juga berhak atas upah berdasarkan surat edaran tersebut.

Apabila pengusaha tidak mampu membayar upah sesuai upah minimum sebagai imbas COVID-19, pengusaha dapat melakukan penangguhan pembayaran upah (jika pengusaha tidak mampu membayar upah sesuai upah minimum), dengan terlebih dahulu melakukan perundingan dengan pekerja/buruh atau serikat 
pekerja/serikat buruh terkait penangguhan tersebut.Penangguhan pembayaran upah minimum oleh pengusaha kepada pekerja/buruh tidak serta-merta menghilangkan kewajiban pengusaha untuk membayar selisih upah minimum selama masa penangguhan.

Berdasarkan uraian tersebut, PHK memang tidak dianjurkan dilakukan. Ada upaya alternatif untuk tetap mempekerjakan pekerja/buruh dan mempertahankan kegiatan usaha sebagaimana diterangkan di atas.

2) Ketentuan Ganti Rugi bagi Pekerja dengan Perjanjian Kerja Waktu Tertentu ("PKWT")

Dalam konteks pekerja dengan sistem PKWT, apabila salah satu pihak mengakhiri hubungan kerja sebelum berakhirnya jangka waktu yang ditetapkan dalam PKWT atau berakhirnya hubungan kerja bukan karena ketentuan sebagaimana dimaksud dalam Pasal 61 ayat (1) Undang-Undang Nomor 13 Tahun 2003 tentang Ketenagakerjaan, maka pihak yang mengakhiri hubungan kerja diwajibkan membayar ganti rugi kepada pihak lainnya sebesar upah pekerja/buruh sampai batas waktu berakhirnya jangka waktu perjanjian kerja.

Pasal 61 ayat (1) Undang-Undang Nomor 13 Tahun 2003 tentang Ketenagakerjaan yang dimaksud berbunyi:

"Perjanjian kerja berakhir apabila:

a. pekerja meninggal dunia;

b. berakhirnya jangka waktu perjanjian kerja;

c. adanya putusan pengadilan dan/atau putusan atau penetapan lembaga penyelesaian perselisihan hubungan industrial yang telah mempunyai kekuatan hukum tetap; atau

d. adanya keadaan atau kejadian tertentu yang dicantumkan dalam perjanjian kerja, peraturan perusahaan, atau perjanjian kerja bersama yang 
dapat menyebabkan berakhirnya hubungan kerja."

Berdasarkan uraian di atas, seorang pekerja/buruh PKWT berhak mendapatkan ganti kerugian ketika terjadi PHK secara sepihak di tengah masa kontraknya. Terkait dengan proses pengajuan PHK juga wajib tunduk pada Undang-Undang Nomor 2 Tahun 2004 tentang Penyelesaian Perselisihan Hubungan Industrial.

\section{b. Pemberlakuan Work From Home sebagai perlindungan tenaga kerja} dalam situasi Pandemi COVID-19

Terkait dengan pemberlakuan work from home (“WFH”) atau bekerja di rumah di tengah wabah corona dapat dikaitkan dengan ketentuan Pasal 86 ayat (1) huruf a Undang-Undang Nomor 13 Tahun 2013 tentang Ketenagakerjaan, di mana setiap pekerja/buruh mempunyai hak untuk memperoleh perlindungan atas keselamatan dan kesehatan kerja.

Perlu diketahui, Keputusan Kepala Badan Nasional Penanggulangan Bencana Nomor 13.A Tahun 2020 tentang Perpanjangan Status Keadaan Tertentu Darurat Bencana Wabah Penyakit Akibat Virus Corona di Indonesia sendiri telah menetapkan pada poin kedua bahwa status keadaan tertentu darurat terkait wabah corona diperpanjang selama 91 hari, terhitung sejak tanggal 29 Februari 2020 sampai dengan tanggal 29 Mei 2020.

Dinas Tenaga Kerja, Transmigrasi, dan Energi Provinsi DKI Jakarta sendiri telah menerbitkan Surat Edaran Dinas Tenaga Kerja, Transmigrasi dan Energi Provinsi DKI Jakarta Nomor 14/SE/2020 Tahun 2020 tentang Himbauan Bekerja di Rumah (Work From Home) yang menindaklanjuti Instruksi Gubernur Provinsi DKI Jakarta Nomor 16 Tahun 2020 tentang Peningkatan Kewaspadaan Terhadap Risiko Penularan Infeksi Corona Virus Disease (COVID-19).

Menurut Surat Edaran Dinas Tenaga Kerja, Transmigrasi dan Energi Provinsi DKI Jakarta Nomor 14/SE/2020 Tahun 2020 tentang Himbauan Bekerja di Rumah (Work From Home), para pimpinan perusahaan diharapkan dapat mengambil langkah pencegahan terkait risiko penularan infeksi COVID-19 dengan melakukan pekerjaan di rumah. 
Langkah-langkah pencegahan yang dapat diambil dikelompokkan menjadi tiga kategori:

a. Perusahaan untuk sementara waktu dapat menghentikan seluruh kegiatan usahanya.

b. Perusahaan untuk sementara waktu dapat mengurangi sebagian kegiatan usahanya (sebagian karyawan, waktu, dan fasilitas operasional).

c. Perusahaan yang tidak dapat menghentikan kegiatan usahanya, mengingat kepentingan langsung yang berhubungan dengan pelayanan kesehatan, kebutuhan bahan-bahan pokok, dan bahan bakar minyak (BBM).

Pengambilan langkah-langkah kebijakan di atas, agar melibatkan para pekerja/buruh dan/atau serikat pekerja/serikat buruh di perusahaan. Selanjutnya, pimpinan perusahaan diminta melaporkan pengambilan langkah kebijakan tersebut pada Dinas Tenaga Kerja, Transmigrasi, dan Energi serta Suku Dinas Tenaga Kerja, Transmigrasi, dan Energi di lima wilayah kota administrasi DKI Jakarta dan Kabupaten Administrasi Kepulauan Seribu.

c. Pemberlakuan prinsip Social Distancing dan Pengenaan Alat Pelindung Diri berdasarkan regulasi Pembatasan Sosial Berskala Besar di Lingkungan Kerja.

Pemberlakuan prinsip social distancing, biasanya dilakukan melalui skema penetapan Pembatasan Sosial Berskala Besar di suatu wilayah. Demikian pula dengan UU No. 6 Tahun 2018 tentang Karantika Kesehatan. Dalam konsideran mengingat, UU ini juga tidak menyebut Pasal 12 UUD 1945 tentang keadaan bahaya, melainkan hanya Pasal 5 ayat (1), Pasal 20, Pasal $28 \mathrm{H}$ ayat (1), Pasal 34 ayat (3) Undang-Undang Dasar Negara Republik Indonesia Tahun 1945. Pada Bagian Kelima UU ini diatur mengenai Pembatasan Sosial Berskala Besar (PSBB), yaitu pada Pasal 59 yang menentukan:

1) Pembatasan Sosial Berskala Besar merupakan bagian dari respons Kedaruratan Kesehatan Masyarakat;

2) Pembatasan Sosial Berskala Besar bertujuan mencegah meluasnya penyebaran penyakit Kedaruratan Kesehatan Masyarakat yang sedang terjadi antar orang di suatu wilayah tertentu; 
3) Pembatasan Sosial Berskala Besar sebagaimana dimaksud pada ayat (1) paling sedikit meliputi:

a. peliburan sekolah dan tempat kerja;

b. pembatasan kegiatan keagamaan; dan/atau

c. pembatasan kegiatan di tempat atau fasilitas umum.

4) Penyelenggaraan Pembatasan Sosial Berskala Besar berkoordinasi dan bekerja sama dengan berbagai pihak terkait sesuai dengan ketentuan peraturan perundangan-undangan.

Dalam bunyi pasal diatas, pemberlakuan Social Distancing menganjurkan untuk meliburkan tempat kerja. Namun, banyak industry yang melibatkan tenaga kerja tidak bisa ditutup begitu saja karena harus memenuhi permintaan kebutuhan masyarakat yang menjadi kebutuhan primer.

Keadaan tersebut seharusnya mewajibkan para pengusaha untuk menerapkan perlindungan terhadap tenaga kerjanya agar tidak terinfeksi virus dan melakukan penularan virus di tempat kerja dengan cara menerapkan Social Distancing di lingkungan kerja dan mewajibkan para pekerjanya menggunakan Alat Pelindung Diri (APD).

Perlindungan tersebut telah diatur dalam Pasal 35 ayat (3) UndangUndang Nomor 13 Tahun 2003 tentang Ketenagakerjaan yang berbunyi :

"Pemberi kerja sebagaimana dimaksud pada ayat (1) dalam mempekerjakan tenaga kerja wajib memberikan perlindungan yang mencakup kesejahteraan, keselamatan, dan kesehatan baik mental maupun fisik tenaga kerja."

Terkait dengan hak-hak setiap tenaga kerja untuk mendapatkan perlindungan kesehatan diatur lebih lanjut dalam Pasal 86 UndangUndang Nomor 13 Tahun 2003 tentang Ketenagakerjaan yang berbunyi

\section{Pasal 86}

1) Setiap pekerja/buruh mempunyai hak untuk memperoleh perlindungan atas:

a. keselamatan dan kesehatan kerja;

b. moral dan kesusilaan; dan

c. perlakuan yang sesuai dengan harkat dan martabat manusia serta nilai-nilai agama. 
2) Untuk melindungi keselamatan pekerja/buruh guna mewujudkan produktivitas kerja yang optimal diselenggarakan upaya keselamatan dan kesehatan kerja.

3) Perlindungan sebagaimana dimaksud pada ayat (1) dan ayat (2) dilaksanakan sesuai dengan peraturan perundang-undangan yang berlaku.

Jelas diterangkan dalam Pasal 86 Undang-Undang Nomor 13 Tahun 2003 tentang Ketenagakerjaan pemberian APD kepada tenaga kerja yang masih bekerja di tengah pandemic COVID-19 wajib diberikan untuk mengupayakan keselamatan dan kesehatan kerja dari setiap pekerja sesuai dengan regulasi yang berlaku pada saat Pandemi COVID-19.

Kemudian, pengusaha juga wajib mengupayakan prinsip Social Distancing sesuai dengan peraturan-perundang-undangan yang berlaku sesuai dengan tempat dan waktu pada saat terjadi pandemic COVID-19 lebih umumnya mengacu pada PP No. 21 Tahun 2020 Tentang PSBB Besar Dalam Rangka Percepatan Penanganan Corona Wrus Disease 2019 (Covid-19) dan Peraturan Menteri Kesehatan Republik Indonesia Nomor 9 Tahun 2020 Tentang PSBB Dalam Rangka Percepatan Penanganan Corona Virus Disease 2019 (Covid-19).

B. Perlindungan Status Kerja Dan Pengupahan Tenaga Kerja Dalam Situasi Pandemic COVID-19 Berdasarkan Perspektif Pembaharuan Hukum

\section{a. Kajian Perbandingan dengan Negara Lain}

Pandemi COVID-19 menyebar ke seluruh pelosok dunia dan mengakibatkan banyak juga problematika ketenagakerjaan di masingmasing negara. Penulis mencoba membandingkan beberapa perlindungan pengupahan dan status kerja yang ada di negara lain pada table berikut ${ }^{5}$ :

\begin{tabular}{|c|c|}
\hline Singapura & Malaysia \\
\hline $\begin{array}{l}\text { - Membayarkan } 25 \text { persen gaji } \\
\text { pekerja dari semua sektor usaha di } \\
\text { negerinya }\end{array}$ & $\begin{array}{l}\text { - Memberi subsidi gaji dengan besaran } \\
\text { bervariasi, sesuai jumlah karyawan }\end{array}$ \\
\hline
\end{tabular}

${ }^{5}$ Dr. Asri Wijayanti, S.H.,M.H, Materi Webinar Dampak Pandemi Covid-19 Terhadap Sektor Ketenagakerjaan Di Indonesia 


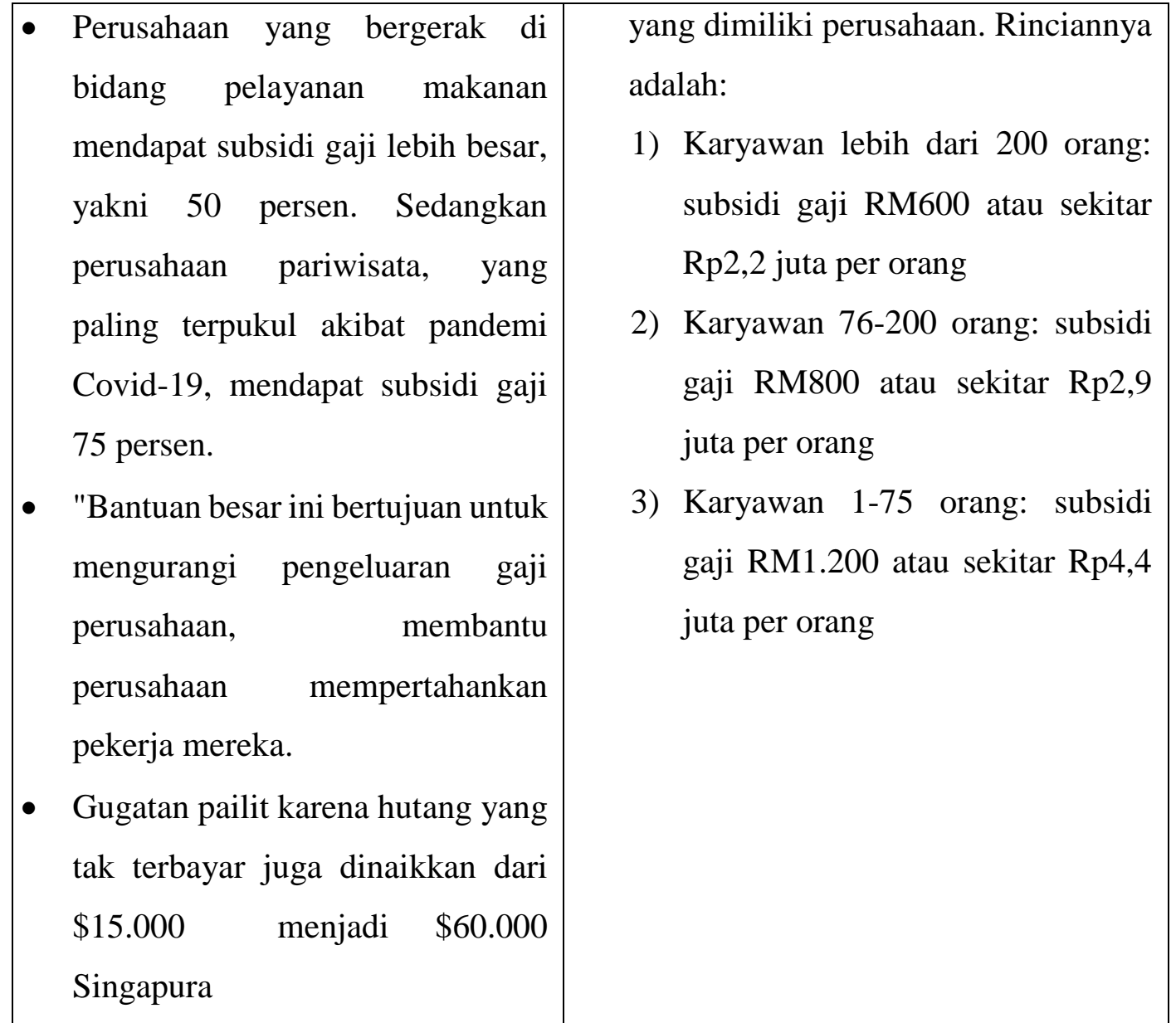

Sumber : Webinar Dampak Pandemi Covid-19 Terhadap Sektor Ketenagakerjaan Di Indonesia

\section{b. Penetapan Perlindungan Status Kerja dan Pengupahan Tenaga Kerja} Dalam Situasi Pandemi COVID-19 melalui Skema Penetapan Peraturan Pemerintah.

Ditetapkannya PERPU No. 1 Tahun 2020 menangguhkan berlakunya pelbagai ketentuan dalam $11 \mathrm{UU}$ dan mengubah materi $1 \mathrm{UU}$, yaitu UU APBN Tetapi, di luar hal-hal yang secara resmi ditangguhkan atau diubah dengan PERPU ini, maka ketentuan UU lainnya tetap berlaku dan tidak boleh dilanggar. Demikian pula undang-undang yang tidak diubah atau ditangguhkan berlakunya oleh PERPU, berarti masih tetap berlaku apa adanya, sehingga juga tidak boleh dilanggar dalam pelaksanaan PERPU No. 1 Tahun 2020 ini. Tujuan PERPU No. 1 Tahun 2020 hanya untuk mengatasi keadaan di bidang ekonomi dan keuangan, isi PERPU hanya menyangkut kebijakan keuangan dan stabilitas sistem keuangan untuk penanganan 
pandemi Covid-19 dan/atau dalam rangka menghadapi ancaman yang membahayakan perekonomian nasional dan/atau stabilitas sistem keuangan.

Dalam keadaan seperti ini, seharusnya penetapan PERPPU tidak hanya sebatas tentang ekonomi fiscal saja, namun bersifat menyeluruh hingga mencakup pada klister ketenagakerjaan. Deklarasi atau Proklamasi keadaan darurat oleh Kepala Negara menyebabkan terjadinya perubahan rezim hukum dari keadaan normal kepada keadaan darurat. Dalam perubahan sistem normatif itu termasuk terjadinya perubahan sistem perilaku ideal dan tindakan-tindakan pemerintahan di luar kebiasaan dalam keadaan normal. Bahkan, keadaan darurat (states of emergency) dapat pula dipakai sebagai alasan atau syarat untuk menunda hak-hak dan kebebasan yang dijamin dalam hukum dasar atau konstitusi suatu negara.

Pembaharuan hukum ketenagakerjaan bertitik tolak pada kolektivitas dan oleh perlindungan yang terus berkembang terhadap buruh. Secara konseptual ia berangkat dari pengandaian adanya relasi asimetris antara buruh dengan majikan, dan karenanya perlu campur tangan negara untuk melindungi buruh yang akan selalu lebih lemah posisinya di hadapan modal dan majikan 6 .

Dalam literatur hukum perburuhan, perubahan ini direfleksikan dalam trend deregulasi dan fleksibelisasi, yang melemahkan fungsi dari perwakilan kepentingan kolektif tradisional dari buruh. Inilah yang juga dialami Indonesia melalui paket 3 UU perburuhan yang diterbitkan antara tahun 2000 hingga 2004. Ketiganya jelas lebih banyak dipengaruhi oleh kepentingan investor daripada kepentingan buruh. ${ }^{7}$ Realita di lapangan juga menunjukan hal yang serupa sebagaimana disampaikan oleh Prof. H.R. Abdussalam, bahwa dari hasil pengamatan dan wawancara dengan para pekerja/buruh, mereka masih diperlakukan secara sepihak baik oleh pengusaha maupun oleh pihak pemerintah. ${ }^{8}$

Seharusnya dalam situasi pandemic COVID-19 seperti ini, Kementrian Ketenagakerjaan tidak hanya mengeluarkan Surat Edaran Menteri

\footnotetext{
${ }^{6}$ Syamsul Khoiri. Peraturan Hukum Perburuhan Dan Sikap Pengadilan: Tarik-Menarik Antara Kepentingan Investor Dan Kepentingan Buruh. Jurnal Hukum \& Pembangunan. Vol. 39. No. 39. tAHUN 2017. Halaman. 1

${ }^{7}$ Loc. Cit. Halaman 2.

${ }^{8}$ H.R. Abdussalam, "Hukum Ketenagakerjaan (Hukum Perburuhan) Yang Telah Direvisi”, Cetakan III, (Jakarta: Restu Agung, 2009), hal. 345-346.
} 
Ketenagakerjaan Nomor M/3/HK.04/III/2020 Tahun 2020 tentang Perlindungan Pekerja/Buruh dan Kelangsungan Usaha dalam Rangka Pencegahan dan Penanggulangan COVID-19. Namun juga perlunya mengeluarkan Peraturan Pemerintah terkait dengan Perlindungan Tenaga Kerja dalam situasi Pandemi COVID-19 agar bersifat lebih mengikat kepada para pengusaha yang masih mempekerjakan tenaga kerjanya ditengah situasi Pandemi COVID-19.

Selain itu, perlunya diadakan inspeksi yang bersifat sinergis antara Kementrian Kesehatan dan Kementrian Ketenagakerjaan terhadap Tempat Kerja yang masih melaksanakan aktivitas pekerjaan pada saat Pandemi COVID-19 sehingga dapat menekan perbuatan semena-mena pengusaha dalam mempekerjakan tenaga kerjanya yang dikhawatirkan dapat menyebabkan penyebaran COVID-19 menjadi tak terkendali dan tidak sesuai dengan asas perlindungan tenaga kerja yang telah diatur dalam Undang Nomor 13 Tahun 2003 tentang Ketenagakerjaan.

\section{Kesimpulan}

Dalam hal perlindungan pengupahan dan perlindungan bagi tenaga kerja di tempat kerja pengusaha dapat melakukan penangguhan pembayaran upah (jika pengusaha tidak mampu membayar upah sesuai upah minimum), dengan terlebih dahulu melakukan perundingan dengan pekerja/buruh atau serikat pekerja/serikat buruh terkait penangguhan tersebut.Penangguhan pembayaran upah minimum oleh pengusaha kepada pekerja/buruh tidak serta-merta menghilangkan kewajiban pengusaha untuk membayar selisih upah minimum selama masa penangguhan. Kemudian, Menurut Surat Edaran Dinas Tenaga Kerja, Transmigrasi dan Energi Provinsi DKI Jakarta Nomor 14/SE/2020 Tahun 2020 tentang Himbauan Bekerja di Rumah (Work From Home), para pimpinan perusahaan diharapkan dapat mengambil langkah pencegahan terkait risiko penularan infeksi COVID-19 dengan melakukan pekerjaan di rumah.

Perlunya mengeluarkan Peraturan Pemerintah terkait dengan Perlindungan Tenaga Kerja dalam situasi Pandemi COVID-19 agar bersifat lebih mengikat kepada para pengusaha yang masih mempekerjakan tenaga kerjanya ditengah situasi Pandemi COVID-19 agar dapat melindungi status kerja supaya terhindar dari Pemutusan Hubungan Kerja. 


\section{E. Daftar Pustaka}

Abdussalam, H.R. 2009. "Hukum Ketenagakerjaan (Hukum Perburuhan) Yang Telah Direvisi”, Cetakan III, (Jakarta: Restu Agung)

Aloysius Uwiyono, Seminar Nasional Online "Pemutusan Hubungan Kerja Sepihak Akibat Pandemi COVID 19”, KEPRI LAWYERS CLUB INDONESIA, Jakata, 5 Mei 2020.

Dr. Asri Wijayanti, S.H.,M.H, Materi Webinar Dampak Pandemi Covid-19 Terhadap Sektor Ketenagakerjaan Di Indonesia

Jimly Asshiddiqie, Seminar Nasional Online "PROBLEMATIKA PERPU COVID-19" Soekanto, Soerjono \& Mamudji, Sri. 2009 Penelitian Hukum Normatif, Suatu Tinjauan Singkat, Rajawali, Jakarta.

Syamsul Khoiri. Peraturan Hukum Perburuhan Dan Sikap Pengadilan: Tarik-Menarik Antara Kepentingan Investor Dan Kepentingan Buruh. Jurnal Hukum \& Pembangunan. Vol. 39. No. 39. Tahun 2017. 